\section{Area under the curve of TSH after levothyroxine withdrawal versus administration of recombinant human TSH (rhTSH): possible implications for fumor growth}

\author{
Área sob a curva de TSH após suspensão da levotiroxina \\ versus administração do TSH recombinante humano: \\ possiveis implicações no crescimento tumoral
}

Pedro Weslley Rosario', Daniela Santos Salles' ${ }^{1}$, Saulo Purisch'

\begin{abstract}
Objective: The levothyroxine withdrawal (L-T4) for some weeks results in prolonged exposure to elevated TSH. In contrast, administration of recombinant human TSH (rhTSH) promotes a short period of hyperthyrotropinemia. The objective of this study was to compare the area under the curve (AUC) of TSH obtained after L-T4 withdrawal versus administration of rhTSH. Methods: Thirty patients received $0.9 \mathrm{mg}$ rhTSH for two consecutive days, and 64 were prepared by L-T4 withdrawal for four weeks, with the latter being reintroduced 48 hour after ${ }^{131}$ I. Measurement of TSH were performed before the first rhTSH ampoule; immediately before and seven and 14 days after ${ }^{131}$ |; before L-T4 withdrawal; and, weekly, up to two months after ${ }^{131}$. Results: The AUC obtained after rhTSH was 4.6 times smaller than that obtained after L-T4 withdrawal (532 versus $2,423 \mathrm{mIU} / \mathrm{L}$ per day). It should be emphasized that, on average, in the latter group, $58.5 \%$ of the AUC corresponded to the period after reintroduction of hormone therapy. Conclusions: Surprising difference in the TSH AUC was demonstrated between rhTSH administration versus L-T4 withdrawal. Arq Bras Endocrinol Metab. 2009;53(6):767-70
\end{abstract}

Keywords

Thyroid neoplasms; tumor growth; recombinant human TSH

\section{RESUMO}

Objetivo: A suspensão de levotiroxina (L-T4) por algumas semanas resulta em exposição prolongada aoTSH elevado. Em contraste, a administração doTSH recombinante (rhTSH) promove um curto período de hipertirotropinemia. $\mathrm{O}$ objetivo deste estudo foi comparar a área sob a curva (do inglês "area under the curve", AUC) do TSH obtida após suspensão da L-T4 versus a administração do rhTSH. Métodos: Trinta pacientes receberam 0,9 mg de rhTSH por dois dias consecutivos, e 64 foram preparados com suspensão da L-T4 por quatro semanas, com reintrodução dessa terapia 48 horas após o radioiodo. As medidas de TSH foram realizadas antes da primeira ampola de rhTSH; imediatamente antes e sete e 14 dias após o ${ }^{131}$; antes da suspensão da L-T4; e, semanalmente, até dois meses após o ${ }^{131}$. Resultados: A AUC doTSH obtida após rhTSH foi 4,6 vezes menor do que a alcançada após suspensão da L-T4 (532 versus $2.423 \mathrm{mUI} / \mathrm{L}$ ao dia). Enfatiza-se que, em média, no último grupo, 58,5\% da AUC correspondeu ao período após a reintrodução da terapia hormonal. Conclusões: Surpreendente diferença na AUC do TSH foi demonstrada entre a administração do rhTSH versus suspensão da L-T4. Arq Bras Endocrinol Metab. 2009;53(6):767-70

Descritores

Neoplasias da glândula tireoide; crescimento tumoral; TSH recombinante humano
1 Departamento de Tireoide, Serviço de Endocrinologia, Santa Casa de Belo Horizonte, Belo Horizonte, MG, Brasil
Correspondence to:

Pedro Weslley Rosario

Centro de Estudos e Pesquisa da Clínica de Endocrinologia e Metabologia (Cepcem) Av. Francisco Sales, 1.111, $5^{\circ} \mathrm{D}-$ Santa Efigênia

30150-221 - Belo Horizonte, MG, Brasil

pedrorosario@globo.com

Received in Feb/25/2009 Accepted in June/2/2009 


\section{INTRODUCTION}

Ctimulation of growth is one of the responses me$\checkmark$ diated by TSH in the normal thyroid. Well-differentiated tumors (papillary and follicular carcinomas) preserve, at least in part, this property of normal tissue. Therefore, although TSH is not the only stimulus and its effect is influenced by other factors, the role of this hormone in the recurrence of these tumors after surgery seems to be well-defined (1).

The classical preparation for ablation or therapy with ${ }^{131} \mathrm{I}$, which consists in levothyroxine withdrawal (L-T4) for some weeks, results in prolonged exposure to elevated levels of TSH, even after reintroduction of hormone therapy (2). In contrast, administration of recombinant human TSH (rhTSH) promotes a short period of hyperthyrotropinemia, with the perspective of distinct effects on tumor growth. In the present study, we compared the area under the curve (AUC) of TSH obtained after L-T4 withdrawal versus administration of rhTSH, considering that this is the best approach to evaluate the intensity of the TSH stimulus $(3,4)$.

\section{METHODS}

The characteristics of the patients have been published previously (5). In summary, 94 patients with well-differentiated thyroid carcinoma aged 18-65 years, who had been submitted to total thyroidectomy and presented no apparent disease after surgery, were studied. L-T4 therapy was initiated immediately after thyroidectomy and ablation with radioiodine $(3.7 \mathrm{GBq}(100 \mathrm{mCi})$ was performed between eight to ten weeks later. Thirty patients received $0.9 \mathrm{mg}$ rhTSH for two consecutive days, followed by ${ }^{131} \mathrm{I}$ administration on the third day; 64 patients were prepared by L-T4 withdrawal during four weeks (acquisition of rhTSH was not feasible), with the latter being reintroduced 48 hour after ${ }^{131} \mathrm{I}$ administration (5). The groups were similar in terms of gender, age and tumor characteristics; all patients presented uptake in the thyroid bed $\leq 2 \%$, and none of them had distant metastases on RxWBS (5). The study was approved by the Ethics Committee on Research of our Institution (Santa Casa de Belo Horizonte), and the subjects gave written informed consent.

Samples for the measurement of TSH were collected before the first rhTSH ampoule; immediately before and seven and 14 days after ${ }^{131} \mathrm{I}$ administration or before L-T4 withdrawal; and weekly, up to two months after ablation. The AUC values were calculated based on mean TSH levels using a standard trapezoidal model.

TSH was measured with a chemiluminescent assay (Advia Centaur System, Bayer Corporation), with an inter-assay coefficient of variation $<6 \%$ for values ranging from 0.26 to $83 \mathrm{mIU} / \mathrm{L}$, and reference values of 0.3 to $5 \mathrm{mIU} / \mathrm{L}$ (euthyroid).

Means were compared between groups by the Student's t-test or the nonparametric Mann-Whitney U test. The Fisher exact test or $\chi^{2}$ test was used to detect differences in the proportion of cases. A p-value of less than 0.05 was considered significant.

\section{RESULTS}

TSH levels were similar in the two groups before rhTSH administration and before L-T4 withdrawal (TSH $<0.1$ $\mathrm{mIU} / \mathrm{L}, 40$ versus 37.5\%; TSH $<2 \mathrm{mIU} / \mathrm{L}, 90$ versus $92.2 \%$, respectively), but were higher in the rhTSH Group immediately before ${ }^{131} \mathrm{I}$ administration (118 \pm 28 versus $85 \pm 23 \mathrm{mIU} / \mathrm{L}, \mathrm{p}<0.05)(5)$. The average daily L-T4 dose was $178 \mu \mathrm{g}$ or $2.2 \mu \mathrm{g} / \mathrm{kg}$, with no difference between groups.

The AUC obtained after rhTSH administration was 4.6 times smaller than that obtained after L-T4 withdrawal (532 versus $2,423 \mathrm{mIU} / \mathrm{L}$ per day; $\mathrm{p}<0.0001$ ) (Figure 1). The AUC ranged from 305 to $906 \mathrm{mIU} / \mathrm{L}$ per day in the rhTSH Group and from 996 to 4,022 $\mathrm{mIU} / \mathrm{L}$ per day after L-T4 withdrawal. It should be emphasized that, on average, in the latter group, $58.5 \%$ (range: $45 \%$ to $71 \%$ ) of the AUC corresponded to the period after reintroduction of hormone therapy.

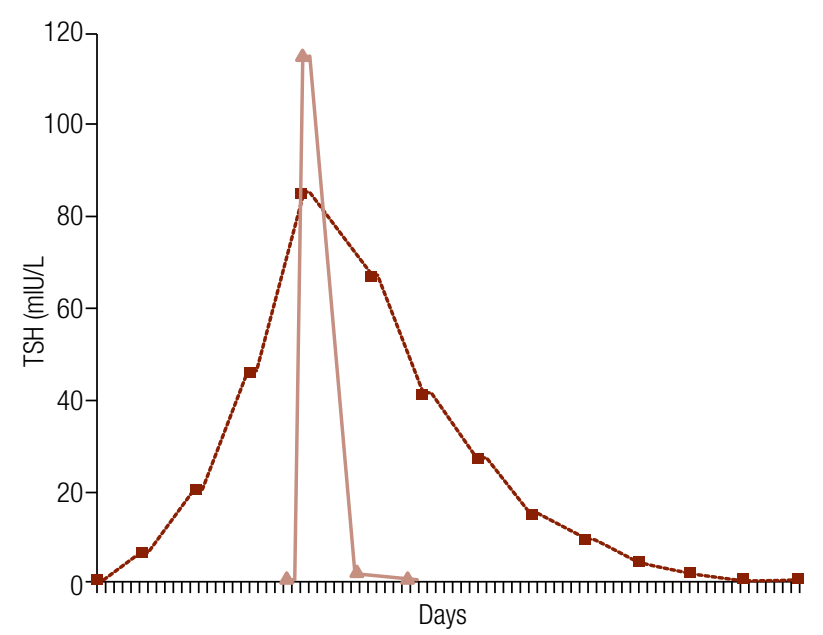

Figure 1. Curve of TSH after L-T4 withdrawal (hachure line) versus administration of rhTSH (continuous line). 


\section{DISCUSSION}

The intensity of the TSH stimulus on responsive tissues has better evaluation if based on the AUC than when the peak TSH is used $(3,4)$. The AUC was approximately 4.5 times smaller after rhTSH administration than after L-T4 withdrawal for four weeks, even in the presence of higher peak TSH, demonstrating that, if adjusted for the same peak concentration, this difference is even greater. Considering only the period after reintroduction of L-T4, Maini, Sciuto and Tofani (6) reported an AUC (mean TSH) of 2,797 mIU/L per day, for a daily dose of $100 \mu \mathrm{g}$, and 1,634 mIU/L per day, for a daily dose of $150 \mu \mathrm{g}$. In the present study, this value was $1,415 \mathrm{mIU} / \mathrm{L}$ per day, since the patients reinitiated therapy using the same daily L-T4 dose that was previously able to normalize TSH $(<2 \mathrm{mIU} / \mathrm{L}$ in $>$ $90 \%$ of cases), on average, $178 \mu \mathrm{g}$ or $2.2 \mu \mathrm{g} / \mathrm{kg}$. Thus, the administration of daily doses of $100 \mu \mathrm{g}$ or $<2 \mu \mathrm{g} / \mathrm{kg}$, unless they were able to normalize or suppress TSH previously, probably resulted in a greater AUC than that demonstrated here. Interestingly, this period (after reintroduction of L-T4) corresponds to the main portion of the TSH AUC but, on this occasion, elevated TSH has no longer any desired purpose since thyroglobulin had already been measured, and radioiodine was taken up by tissues.

The clinical consequences of the difference demonstrated here deserve some comments. With respect to thyroglobulin secretion, the serum levels of this protein are, in fact, lower after rhTSH administration when compared with hypothyroidism, but there is no difference in the sensitivity of detection of metastases (7-9). Even if ${ }^{131} \mathrm{I}$ uptake is lower with rhTSH, other mechanisms, such as a longer effective half-life, guarantee a similar radiation in the target tissue $(10,11)$. In this respect, the efficacy of rhTSH in remnant ablation has been widely demonstrated $(5,10,12-15)$. Thus, the difference in the TSH stimulus does not compromise the efficiency of rhTSH in situations in which its use is suggested and recommended $(3,8,9)$.

On the other hand, the lower TSH stimulus associated with the administration of rhTSH may have implications in tumor growth. The impact of this difference might be dramatic in patients with known metastases, but there is no comparative studies about the efficacy of rhTSH versus hypothyroidism in this group; rhTSH has still not been approved for this purpose. The advantage of rhTSH in providing a smaller AUC of TSH is only explored in cases of metastases at critical sites, in which tumor expansion is limited and L-T4 withdrawal would increase the chance of severe symptomatic growth $(3,8,9)$. Although possible, the increase of metastases after administration of rhTSH results from edema and intralesional hemorrhage and is probably prevented by preparation with corticosteroids (8). In thyroid remnant ablation, although not presenting apparent disease, some patients are at high risk of persistent occult metastases $(16,17)$. These patients may particularly benefit from preparation with rhTSH by preventing the progression of these metastases with a TSH stimulus, that is much lower than that obtained with L-T4 withdrawal.

Although the efficacy of rhTSH in stimulating serum thyroglobulin and in the ablation of thyroid remnants has been well-documented in the literature, the surprising difference in the TSH AUC demonstrated between rhTSH administration and L-T4 withdrawal suggests the perspective of distinct effects on tumor growth and indicates an interesting potential advantage of preparation with rhTSH.

Acknowledgements: this study was not supported by research funds.

Disclosure: no potential conflict of interest relevant to this article was reported.

\section{REFERENCES}

1. McGriff NJ, Csako G, Gourgiotis L, Lori CG, Pucino F, Sarlis NJ. Effects of thyroid hormone suppression therapy on adverse clinical outcomes in thyroid cancer. Ann Med. 2002;34(7-8):554-64.

2. Rosario PW, Fagundes TA, Rezende LL, Padrao EL, Borges MA, Barroso AL. Assessing hypothyroidism in the preparation of patients with thyroid cancer: cardiovascular risk, renal function, drug metabolism, persistence of elevated thyroid-stimulating hormone, and absence from work. Endocrinologist. 2006;16(1):25-9.

3. Schlumberger M, Borget I, De Pouvourville G, Pacini F. Recombinant human thyroid-stimulating hormone: use in papillary and follicular thyroid cancer. Horm Res. 2007;67(suppl 1):132-42.

4. Schlumberger $M$, Pacini $F$. Recombinant human thyroid-stimulating hormone (rhTSH): use in papillary and follicular thyroid cancer. In: Thyroid tumors. 3rd edition. Paris: Éditions Nucleón, 2006. p.167.

5. Rosário PW, Borges MA, Purisch S. Preparation with recombinant human thyroid-stimulating hormone for thyroid remnant ablation with $131 \mathrm{l}$ is associated with lowered radiotoxicity. $\mathrm{J}$ Nucl Med. 2008;49(11):1776-82.

6. Maini $\mathrm{CL}$, Sciuto $\mathrm{R}$, Tofani A. TSH suppression by octreotide in differentiated thyroid carcinoma. Clin Endocrinol (Oxf). 1994;40(3):335-9.

7. Haugen BR, Pacini $F$, Reiners $C$, Schlumberger M, Ladenson PW, Sherman SI, et al. A comparison of recombinant human thyrotropin and thyroid hormone withdrawal for the de- 
tection of thyroid remnant or cancer. J Clin Endocrinol Metab. 1999;84(11):3877-85.

8. Rosário PW, Fagundes TA, Purisch S, Padrão EL, Rezende LL, Barroso AL. Recombinant TSH in ablative therapy and follow-up of patients with differentiated thyroid carcinoma. Arq Bras Endocrinol Metabol. 2005;49(3):350-8.

9. Graf H, Paz-Filho G. Recombinant human TSH use in differentiated thyroid cancer. Arq Bras Endocrinol Metabol. 2007;51(5):806-12.

10. Pacini F, Ladenson PW, Schlumberger M, Driedger A, Luster $\mathrm{M}$, Kloos RT, et al. Radioiodine ablation of thyroid remnants after preparation with recombinant human thyrotropin in differentiated thyroid carcinoma: results of an international, randomized, controlled study. J Clin Endocrinol Metab. 2006;91(3):926-32.

11. Hänscheid $H$, Lassmann $M$, Luster $M$, Thomas SR, Pacini F, Ceccarelli $\mathrm{C}$, et al. lodine biokinetics and dosimetry in radioiodine therapy of thyroid cancer: procedures and results of a prospective international controlled study of ablation after rhTSH or hormone withdrawal. J Nucl Med. 2006;47(4):648-54.

12. Barbaro D, Boni G, Meucci G, Simi U, Lapi P, Orsini P, et al. Recombinant human thyroid-stimulating hormone is effective for radioiodine ablation of post-surgical thyroid remnants. Nucl Med Commun. 2006;27(8):627-32.
13. Taïeb D, Sebag F, Cherenko M, Baumstarck-Barrau K, Fortanier C, Farman-Ara1 B, et al. Quality of life changes and clinical outcomes in thyroid cancer patients undergoing radioiodine remnant ablation with recombinant human thyrotropin: a randomized controlled study. Clin Endocrinol. (Oxf) 2008 (in press).

14. Tuttle RM, Brokhin M, Omry G, Martorella AJ, Larson SM, Grewal $\mathrm{RK}$, et al. Recombinant humanTSH-assisted radioactive iodine remnant ablation achieves short-term clinical recurrence rates similar to those of traditional thyroid hormone withdrawal. J Nucl Med. 2008;49(5):764-70.

15. Chianelli M, Todino V, Graziano F, Panunzi C, Pace D, Guglielmi $\mathrm{R}$, et al. Low dose $(2.0 \mathrm{GBq} ; 54 \mathrm{mCi})$ radioiodine postsurgical remnant ablation in thyroid cancer: comparison between hormone withdrawal and use of rhTSH in low risk patients. Eur $\mathrm{J}$ Endocrinol. 2009;160(3):431-6.

16. Leboulleux S, Rubino C, Baudin E, Caillou B, Hartl DM, Bidart JM, et al. Prognostic factors for persistent or recurrent disease of papillary thyroid carcinoma with neck lymph node metastases and/or tumor extension beyond the thyroid capsule at initial diagnosis. J Clin Endocrinol Metab. 2005;90(10):5723-9.

17. Rosario PW, Borges MA, Alves MF, Purisch S, Padrão EL, Rezende $\mathrm{LL}$, et al. Follow-up of high-risk patients with differentiated thyroid cancer without persistent disease after initial therapy. Arq Bras Endocrinol Metabol. 2006;50(5):909-13. 